\title{
Analysing Science Test Items and Higher Order Thinking Skills of Fifth Graders
}

\author{
Mardi
}

SDN Kedungrejo 3 Muncar, Banyuwangi, Indonesia 68472

\begin{abstract}
Indonesian students got low achievement in many international studies of evaluation, such as in Trend in International Mathematics and Science Study (TIMSS). It is because they unfamiliar with higher order thinking skill questions. Generally, assessment in Indonesia contains less of higher order thinking questions and do not fit with the international standard of evaluation. The purposes of this study were to identify the test items of Test of Standarisasi Hasil Belajar (SHB) and to examine the capability of students of fifth grade to answer higher order thinking skills (HOTS) questions. The method uses was mix method (qualitative and quantitative). Test Standarisasi Hasil Belajar (SHB) Year 2017/2018 of Banyuwangi Regency for fifth grade was used. Twenty-seven fifth graders were participated in paper test. The result showed that the test contains of cognitive domain of knowing, applying, and reasoning of $48.9 \%, 40 \%$ and $11.1 \%$, respectively. The test of capability of students to answer HOTS questions revealed low achievement of $80 \%$ and high achievement of 5\%. In summary, the reasoning domain of the test should be more developed to encourage students' capability in answering HOTS questions.
\end{abstract}

Keywords: science test items, TIMSS, HOTS, fifth grade.

\section{INTRODUCTION}

One of the internationally recognized educational parameters is Trend in International Mathematics and Science Study (TIMSS). TIMSS is an international study used to measure students' ability in mathematics and science. The objective of TIMSS is to measure the curriculum implementation in each country and the students' achievements in mathematics and science. Indonesia's participation in TIMSS began in 1999 for grade 8, and began in 2015 for grade 4 . The achievement of grade 4 of Indonesian students in science showed a mark of 397 which was under the international average (500) and included in the low category benchmark. The result puts Indonesian students in rank 45 of 48 countries (Martin, et al., 2016). Similar results were obtained by grade 8 students on four occasions in TIMSS (Martin, et al., 2012; Mullis, et al., 2013; Utomo, et al., 2018a, b).

The low achievement of science in TIMSS, among others, is due to the ability of Indonesian students on average still on the knowing aspect and they are not accustomed to solve the problems of applying and reasoning. While the cognitive domains in TIMSS 2015 include knowing, applying and reasoning with a $40 \%$ percentage of cognitive domain knowing, $40 \%$ applying and $20 \%$ reasoning (Mullis, et al., 2013). The difficulties of Indonesian students in dealing with these problems are caused by unfamiliarity with higher order thinking skills (HOTS) questions so that their critical thinking skills are low and cause students to make mistakes frequently (Utomo, et al., 2018b). HOTS in the TIMSS questions are accommodated in the cognitive reasoning domain, which includes analyze, evaluate and create (Utomo, et al., 2018 a).

Improving the quality of the evaluation in Indonesia has already begun by adapting some TIMSS questions into the national exam (UN) questions (Puspitarini, 2014). This is a first step to improve the quality of evaluation questions used and to familiarize students with resolving international standard issues. Habituation performed can affect a person's cognitive development. Such habituation efforts need

Bioedukasi Vol. XVI. No.1 April 2018 
to be supported by teachers as the main practitioners of education. Teachers should be able to make evaluation formulations of higher order thinking to encourage and assess students' cognitive abilities appropriately (Utomo, et al., 2018a). One of the evaluations done in the school was the test of Standarisasi Hasil Belajar (SHB). In order to find out whether the exam created contains HOTS problems that are adequate and in accordance with TIMSS standards, it is necessary to analyze the items in the SHB test. Furthermore, HOTS analysis is done in the SHB test to determine the ability of students in answering HOTS questions.

\section{RESEARCH METHOD}

This research used mixed method of qualitative and quantitative. The qualitative research used content analysis method, that was analyzed the item of science SHB test of Banyuwangi Regency academic year of 2017/2018 based on cognitive domain of
TIMSS 2015. Then it continued by testing the HOTS category of cognitive reasoning domain obtained to 27 students of fifth grade of SDN Karangrejo 3 Muncar, Banyuwangi, Indonesia. The aim of the test was informed to the students before conducting the research. The percentage of correct answers from students' answer was calculated.

\section{RESULTS AND DISCUSSION Identification of Test Item of $\mathrm{SHB}$}

Cognitive domains contained in science SHB Test based on cognitive domains TIMSS 2015 showing the results of a total of 45 questions there were contains of 38 questions of knowing cognitive domain, 2 questions of applying cognitive domain and the remaining 5 questions of reasoning cognitive domain (Table 1).

Table 1. Cognitive domain of SHB Test

\begin{tabular}{|c|c|c|c|c|}
\hline $\begin{array}{c}\text { Cognitive } \\
\text { domain }\end{array}$ & Aspect & $\begin{array}{c}\text { Number of test } \\
\text { item }\end{array}$ & Quantity & Percentage (\%) \\
\hline \multirow[t]{3}{*}{ Knowing } & Recall/Recognize & $\begin{array}{c}(1),(2),(9), \\
(10),(14),(16), \\
(20),(22),(24), \\
(26)-(31), \\
(36),(38),(42), \\
(45)\end{array}$ & 19 & 42.2 \\
\hline & Classify/order & $(5),(8),(43)$ & 3 & 6.7 \\
\hline & Measure & - & - & \\
\hline \multirow[t]{3}{*}{ Applying } & Determine & $\begin{array}{l}\text { (7), (12), (17), } \\
(19),(33),(35)\end{array}$ & 6 & 13.3 \\
\hline & Use model & $\begin{array}{c}(3),(4),(13), \\
(15),(18),(21), \\
(23),(32),(34), \\
(44)\end{array}$ & 9 & 20 \\
\hline & Implement & $(6),(25),(36)$ & 3 & 6.7 \\
\hline \multirow[t]{4}{*}{ Reasoning } & Analyze & $\begin{array}{c}(11),(37),(39), \\
\quad(40),(41)\end{array}$ & 5 & 11.1 \\
\hline & Evaluate & - & - & \\
\hline & Create & - & - & \\
\hline & Total & & 45 & 100 \\
\hline
\end{tabular}

Bioedukasi Vol. XVI. No.1 April 2018 
It can be seen that the SHB test contains of knowing of $48.9 \%$, applying of $40 \%$ and reasoning of $11.1 \%$ (Table 1). The SHB test has the same percentage of applying cognitive domain as TIMSS 2015, but more on knowing and less on reasoning when compared with TIMSS 2015. In TIMSS 2015 test items, the percentage of domain knowing, applying, and reasoning is $40 \%$, $40 \%$, and $20 \%$, respectively.

In TIMSS issues aspects such as integrating / synthesizing and reasoning domain are questions that are included in higher order thinking skills (HOTS). Utomo, et al. (2018a) concluded that higher order thinking skills have important role in understanding science and problem solving in TIMSS test items. This is related to the results of the SHB test analysis which was contained a low number of reasoning questions. This result consistent with Boyd (2008) study, which indicated that the majority of teachers' ratings are focused on the lower levels of Bloom's Taxonomy.
These studies reflect the tendency of the assessment methods used in the schools to recall the information or to do routine questions. Assessment in Indonesia mostly measures the cognitive domain until applying level especially in elementary school (Wasis, 2014). Whereas, assessment can be implemented to help the students in improving their HOTS (Van den Berg, 2008). HOT's question can encourage the students to think deeply about the lesson as well (Barnett \& Francis, 2012).

\section{Ability of students in HOTS}

The identification result of test of LOS (Table 1) showed that five test items are HOTS questions. These five test items were tested to students and the result revealed that more than a half of class got low mark and very low mark, which are $37 \%$ and $43 \%$, respectively (Table 2). Thus, students categorized into low achievement were very high (80\%) compared with high achievement (5\%).

Table 2. Students' result of HOTS test items

\begin{tabular}{ccccc}
\hline \multirow{2}{*}{ Test item } & $\begin{array}{c}0-40 \\
\text { (very low) }\end{array}$ & $\begin{array}{c}\text { Number of student with score (\%) } \\
41-60 \\
\text { (low) }\end{array}$ & $\begin{array}{c}61-80 \\
\text { (intermediate) }\end{array}$ & $\begin{array}{c}81-100 \\
\text { (high) }\end{array}$ \\
\hline 11 & 40.7 & 40.7 & 14.8 & 3.7 \\
37 & 44.4 & 37 & 14.8 & 3.7 \\
39 & 37 & 37 & 18.5 & 7.4 \\
40 & 44.4 & 40.7 & 11.1 & 3.7 \\
41 & 48.2 & 29.6 & 14.8 & 7.4 \\
\hline Average $(\%)$ & 43 & 37 & 15 & 5 \\
\hline
\end{tabular}

This study results are in line with the TIMSS 2015 science test result. The result of TIMSS 2015 on grade 4 science, Indonesia got a score of 397 and ranked 45 out of 48 participating countries. Rahmawati (2016) states that Indonesian students need to strengthen their abilities for integrating information, drawing conclusions, and generalizing the knowledge they have. The TIMSS results showed that Indonesia students are weak in the cognitive domain especially on reasoning.
These results show that students' ability in solving HOTS problems was very low. The HOTS contained in this test was analysis, i.e. breaking material into its constituent parts and determining how the parts are related to each other and to an overall structure. For example: comparing, contrasting, differentiating, separating, identifying, relating, illustrating, etc. (Krathwol, 2002). The results of this study are in line with the results of the TIMSS 2015 science test. Results of TIMSS 2015 in science of grade 4, Indonesia got a low 
Rahmawati. (2016). Hasil TIMSS 2015 [handout powerpoint slides]. Accessed from http://puspendik.kemdikbud.go.id/se minar/upload/RahmawatiSeminar\%20 Hasil\%20TIMSS\%202015.pdf

Utomo, A.P., Narulita, E., \& Shimizu, K. (2018a). Diversification of reasoning science test items of timss grade 8 based on higher order thinking skills: a case study of Indonesian students. Journal of Baltic Science Education, 17(1): 152-161.

Utomo, A.P., Narulita, E., Yuana, K., Fikri, K., \& Wahono, B. (2018b). Students' Errors in solving science reasoning-domain of Trends In International Mathematics and
Science Study (TIMSS). Jurnal

Pendidikan IPA Indonesia, 7(1), 4853.

Van den Berg, G. (2008). The use of assessment in the development of higher order thinking skills. Africa Education Review, 1(2), 279-294.

Wasis. (2014). Analyzing physics items of UN, TIMSS, and PISA-based on higher-order thinking and scientific literacy. In Sutrisno, H., Dwandaru, W.S.B., Krisnawan, K.P., Darmawan, D., Priyambodo, E., Yulianty, \& E. Nurohmah, S. (Eds.), Proceeding of International Conference on Research, Implementation and Education of Mathematics and Sciences 2014 (pp. 147-154). Yogyakarta, Indonesia: Yogyakarta State University. 